\title{
The impact of educational attainment on household poverty in South Africa: A case study of Limpopo province
}

\section{Fru Awah Wanka \& Ravinder Rena}

To cite this article: Fru Awah Wanka \& Ravinder Rena (2019) The impact of educational attainment on household poverty in South Africa: A case study of Limpopo province, African Journal of Science, Technology, Innovation and Development, 11:5, 597-609, DOI: 10.1080/20421338.2018.1557368

To link to this article: https://doi.org/10.1080/20421338.2018.1557368

Published online: 28 May 2019.

Submit your article to this journal $\sqsubset$

Џll Article views: 232

Q View related articles $\sqsubset$

View Crossmark data ¿ 


\title{
The impact of educational attainment on household poverty in South Africa: A case study of Limpopo province ${ }^{1}$
}

\author{
Fru Awah Wanka ${ }^{1}$ and Ravinder Rena $\mathbb{B}^{2 *}$ \\ ${ }^{1}$ Institute for Social Development, University of the Western Cape, Bellville, South Africa \\ ${ }^{2}$ NWU Business School, North-West University, Mmbatho, South Africa \\ *Corresponding author email: ravinder.rena@gmail.com
}

The provision of education in South Africa during the apartheid regime was poor, particularly for the African population
and especially those living in the homelands. This has hindered those lacking the required skills from obtaining lucrative
employment and earning prospects. The Income and Expenditure Survey data conducted by Statistics South Africa, for the
period 1995, 2000, 2005/06 and 2010/11 were used to carry out this investigation. The official absolute income poverty
lines of R3864 (lower bound) and R7116 (upper bound) per annum in 2000 prices were used. In order to establish the
relationship between education and poverty status of an individual, a probit regression model was used. This model
helped to determine the relationship between the head of a household's level of education and the poverty status of the
household. The results obtained reveal that there is a strong tendency for lower educational attainment to be associated
with a higher prevalence of household poverty. This study aims at investigating the impact of a household head's
educational attainment level on the poverty status of the individual household in South Africa, using Limpopo province
as a case study. This study seeks to establish whether education has an effect on poverty alleviation in Limpopo province.

Keywords: educational attainment, poverty, human capital, household head, households employment and earnings, signalling theory, South Africa, Limpopo province

\section{Introduction}

Poverty is a phenomenon that is multidimensional in nature and its meaning varies from one individual to another (Alkire and Foster 2011; Batana 2013; Bossert, Chakravarty, and D'Ambrosio 2013; Jansen et al. 2015). It can be seen as a failure to attain certain capabilities, absolute or relative, ${ }^{2}$ or a lack of income to meet a certain standard of living in a given society (Jansen et al. 2015). It can be chronic or temporary ${ }^{3}$, is often linked with underdevelopment, economic exclusion and vulnerabilities, and sometimes closely correlated with inequality (Mbuli 2008; Van der Berg 2008; Jansen et al. 2015). The definition of poverty employed determines its measurement.

According to Bloom, Canning, and Chan (2005), Palmer et al (2007), Thomson (2008) and Badat and Sayed (2014), education could be seen as a product and/ or a tool that leads to changes in both rural and urban communities. It creates environmental consciousness and sustainability that enables people to cultivate values such as health care, human rights and cultural conservancy. They established that education increases human capital, social values, self-esteem and capacity development. When there is a high level of cultural understanding, coupled with quality supply of highly skilled labour gained through good education, development can be stimulated and poverty reduced. Hence, good quality education is a primary factor in achieving poverty alleviation in a society, as long as there is an environment to absorb the concomitant skills (Navaratnam, 1986).

Although poverty is a global problem, due to the unique nature of apartheid in South Africa, which was based on legislative segregation, poverty greatly affected blacks, coloureds and Indians in the country (Aliber 2001; Leibbrandt et al. 2010; Bhorat and Van der Westhuizen 2013). During this period, equal access to quality education, employment, resources and services were denied to these racial groups, particularly blacks, all as part of a deliberate attempt to retard their quality of life (Mokgotho 2010; Badat and Sayed 2014; Spaull 2015). As a result, the racial dimension of poverty endures amongst these racial groups in the country. The introduction of the Bantu Education Act of 1954 prescribed educational access based on race in favour of white communities. This greatly affected educational attainment of South Africans, particularly blacks. As such, it contributed greatly to the high poverty rates prevalent particularly amongst black communities (Schuster 2011).

After the abolition of apartheid in 1994, the provision of education on the basis of equality and quality to all South Africans was seen as a priority by the new government (Waghid and Schreuder, 2000). Waghid and Schreuder (2000) stated that the issue of eliminating deep poverty levels prevalent particularly in rural communities of the country (particularly KwaZulu-Natal, Eastern Cape and Limpopo provinces) was also the main focus of the democratic government. Von Kotze (2007) noted that in 1994, education was the new government's fundamental developmental tool to fight illiteracy and provide essential skills that could help alleviate poverty. This led to the introduction of Adult Basic Education and Training (ABET) in 1995 (McKay 2007). The lack of compulsory education and stringent policies during apartheid caused many children not to attend school or disrupted school attendance between 1976 and 1994. This left many people without education, contributing to a great need for ABET. However, Waghid and Schreuder (2000) ascertained that due to a lack of skills and resources, most people, particularly blacks, could not succeed. Notwithstanding, the government is making efforts to encourage education by investing in education. 
Statistics from the World Bank (2018) indicate that based on the South African government's total expenditure on education as a percentage of gross domestic product (GDP) from 2000 to 2016, expenditure on education decreased from $5.4 \%$ in 2000 to $5.1 \%$ in 2005 and, thereafter, from 2010 to 2016 it has been on a constant rise from $5.7 \%$ to $6.0 \%$ respectively as shown in Figure 1. According to Statistics South Africa (2017), in the 2015/2016 fiscal year, total expenditure on education was R285,735 million, broken down as follows: spending by the provincial governments (R201 202 million); followed by higher education institutions (R61 168 million); national government (R13 208 million); and extra-budgetary accounts and funds (R10,156 million), as shown in Figure 2.

Most past research carried out in South Africa on education and poverty has proved that there is a negative relationship between these factors (Badat and Sayed 2014; Spaull 2015). This implies that the higher an individual's level of education, the less prone he/she is to poverty while the poorer an individual is, the less likely it is for him/her to further his/her education (Van der Berg 2002; Armstrong, Lekezwa, and Siebrits 2008 \& Van der Berg 2008; Botha 2010; Badat and Sayed 2014; Spaull 2015). Given the level of poverty in Limpopo province and the incessant emphasis on the importance of

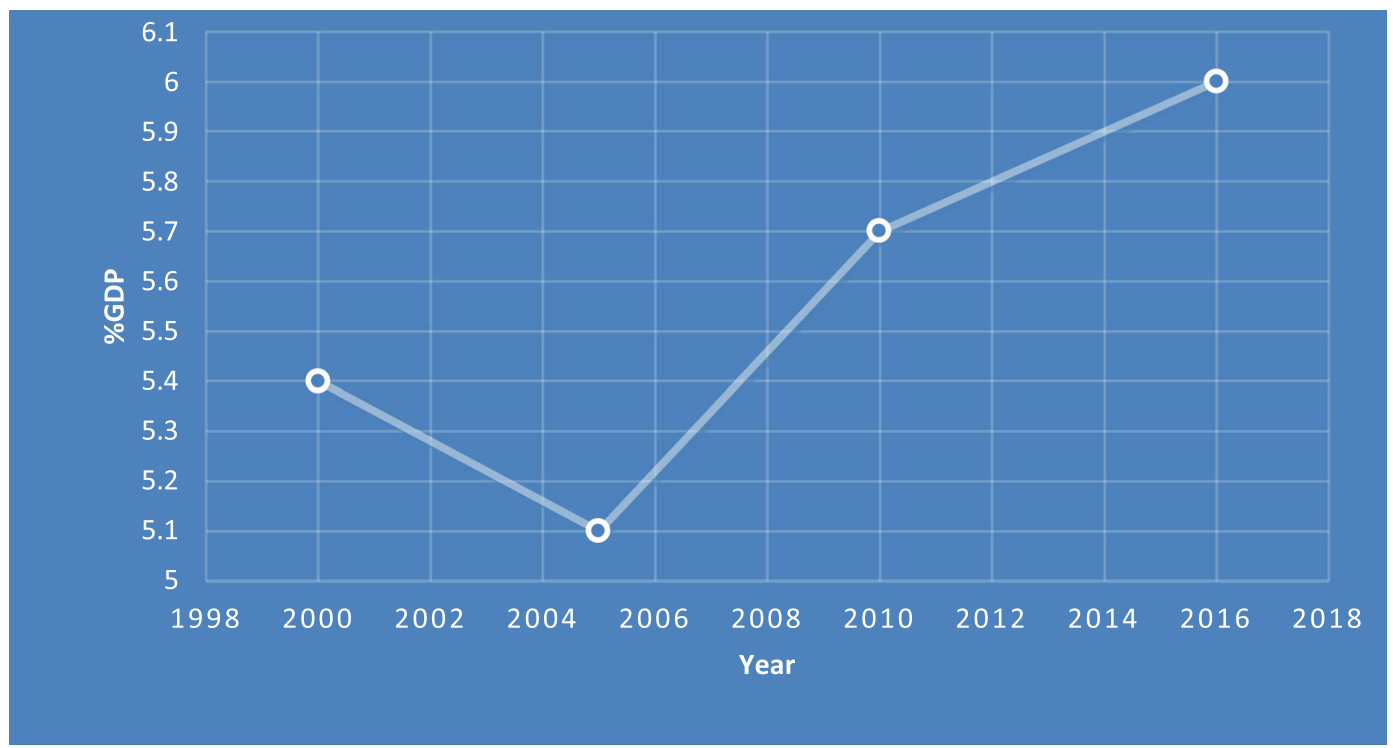

Figure 1: Government expenditure on education (total \%GDP) from 2000-2016.

Source: World Bank Indicators (2018)

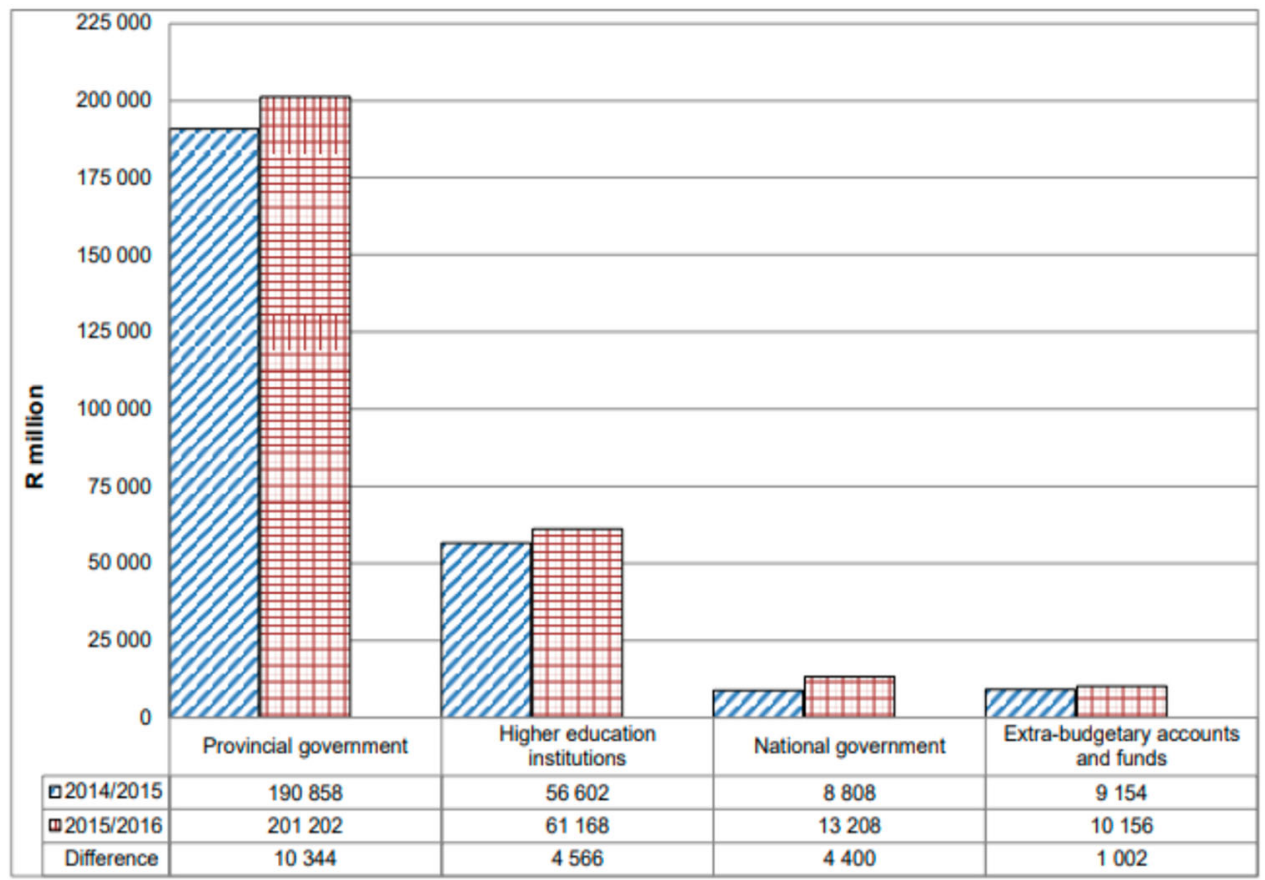

Figure 2. Type of general government institution spending on education for the 2014/2015 and 2015/2016 fiscal years Source: Financial statistics of consolidated general government 
education, none of the previous research explores the link between schooling and poverty in this province in any great depth.

Apart from Van der Berg (2002) and Botha (2010) who, to a certain extent, have analyzed the impact of education on poverty in South Africa, no other study has clearly tested for this, most especially the impact of the educational attainment level of the household head on household poverty, particularly in Limpopo province, despite the low level of educational attainment in the region. This article aims use four datasets to fill this gap in the literature. The research aims at achieving the following: 1) illustrate the extent of poverty in Limpopo province; 2) show the rate of poverty based on level of education attained; 3 ) show the rate of educational attainment in terms of area type, gender and race in the province; and 4) demonstrate how educational attainment can influence the poverty status of an individual or household. The study hypothesized that poor educational attainment of household heads leads to poverty within households

\section{Literature review \\ Theoretical evidence}

According to Appleton (2001), Leibbrandt et al. (2012), Borjas (2016) and Mamman et al. (2018) human capital theory draws links between education and poverty with respect to education as a means to reduce poverty. Investing in education leads to the creation of skills which improves productivity and increases the chances of obtaining employment and earning higher future incomes. These studies show an empirically strong relationship between workers' wage and educational levels. Furthermore, Macerinskiene and Vaiksnoraite (2006) in Naeem (2013) affirmed that in terms of micro-economics, human capital theory depends on the fact that an individual acquires competences and skills through education, which are transferable and negotiable in the labour market, have a transactional value and a direct impact on an individual's average income.

Kjelland (2008), using signalling theory explained that in most cases individuals use their educational level to signal broad sets of inherent productive characteristics which employers cannot observe, and that educational attainment does not necessarily result in directly enhancing productivity. In addition, Weiss (1995) and Levels, Van der Velden, and Di Stasio (2014) argued that this theory is mainly pertinent for those with productive skills or aptitudes not easily identified by employers. As such, education signals the existence of human capital, thereby, resolving information asymmetries. Employers also use educational attainment to make employment decisions and set employees' wages on the basis that those with more education are more productive (Page 2010).

According to Van der Berg (2007) and Spaull (2015), there is an inverse relationship between education and poverty. This implies the lower the educational level of a household, the more likely it is that poverty might prevail in the household. Armstrong, Lekezwa, and Siebrits (2008), Badat and Sayed (2014) and Jansen et al.
(2015) further noted that individuals with low educational levels are likely to be poorer than those with higher education levels. In addition, Tilak (2002) argued that poor education and income poverty are mutually reinforcing. This indicates that the lack of education is one of the main causes of income poverty and income poverty retards people from overcoming poverty of education. Schuster (2011) in Botha (2010) argued that students from poor homes are less likely to complete their education up to a certain level, not because they are not intelligent, but because of the low rate of enrolment due to insufficient funds to enrol in school.

This shows that although lack of education may lead to poverty, inadequate financial resources might also elucidate the incapability of obtaining a satisfactory educational level in the first case. This endogeneity problem can be dealt with by using instrumental variable regressions, for instance, two-stage least squares. In practice, however, it is difficult to find a specific instrumental variable because such an instrument would need to be correlated with the endogenous explanatory variable and uncorrelated with the error term. As such, the direction of causality between education and poverty is therefore not clear, and the estimated parameter(s) cannot be accepted as entirely conclusive.

\section{Empirical evidence}

Weber et al. (2007) noted that encouraging students to stay in school and improve their quality of education is one possible approach to reducing poverty and raising local welfare. Using the US Panel Study of Income Dynamics data, they found that households headed by a well-educated person have a lower probability of being poor. Education had a great effect on the poverty status of households, that is, for each additional year of schooling (further education) by a household head, that household was $39 \%$ less likely to be poor, which is lower than households whose heads do not further their education.

According to Njong (2010), using the Cameroon Household Survey (CHS) conducted in 2001, education has an inverse relationship with an individual's poverty status, that is, the more educated an individual becomes, the lower the likelihood of him/her being poor. This is an indication that education is a critical determinant of the incidence of poverty. Education has a negative impact on poverty, implying that the chances of an individual escaping poverty increase as his/her level of education increases. Furthermore, a study carried out by Ijaiya and Nuhu (2011), using questionnaires based on the methods of the Federal Office of Statistics (FOS), the National Integrated Survey of Households (NISH) and the World Bank Living Standards Measurement Study (WBLSMS) on Ilorin Metropolis in Nigeria, found that an important determinant of poverty is educational level. For example, their findings revealed that poverty is less prevalent amongst households in which the head had attained a higher level of education.

With respect to evidence from South Africa, using Stats SA data of 1995 and 2002, Mbuli (2008) found that $33.12 \%$ and $32.30 \%$ of those without schooling in 1995 and 2002 respectively were unemployed, whereas 
the rate was lowest (6.44\% and $15.37 \%)$ amongst those with tertiary education in the given years, respectively. One can therefore assume that those without schooling (and less schooling) are more likely to be poor, since they are most likely to be unemployed. Woolard (2002) found that in $1998,58 \%, 53 \%, 34 \%, 15 \%$ and $5 \%$ of adults, who had no, primary, incomplete secondary, complete secondary and tertiary education in South Africa, respectively, were poor. In addition, Armstrong, Lekezwa, and Siebrits (2008) using the IES 2005/2006 data and a poverty line of R322 per capita per month in 2000 prices, ascertained that as an individual's level of education increases, the rate of falling into poverty is likely to decrease. Those with degrees had the lowest poverty rate of $1.2 \%$, while those with no schooling had $66.3 \%$.

Furthermore, Klasen (1997), using the Southern African Labour and Development Research Unit (SALDRU) survey data of 1993 found that about $80 \%$ of poor households are headed by someone with no level of education. This is because those with no schooling have less chances of being employed and earning decent wages. As such, poverty prevails less in households with well-educated heads. With respect to reverse causality, inadequate access to quality education is also recognized as a significant consequence of poverty, which helps to replicate inter-generational poverty. In addition, Pauw et al (2006) asserted that unemployment is highest among holders of certificates or diplomas in comparison to those with degrees. In their findings, approximately $82 \%$ of those with certificates and diplomas in 2005 were unemployed compared to about $18 \%$ for degree holders.

\section{Data and methodology}

The data used for this study is the Income and Expenditure Survey (IES), conducted every five years by Statistics South Africa, for the periods 1995, 2000, 2005 and 2010. IES 1995 took place in September 1995, IES2000 was conducted in October 2000, IES2005/2006, known as IES2005, took place between September 2005 and August 2006 and IES2010/2011, known as IES2010, took place between September 2010 and August 2011. Across these years, the sample size for South Africa was approximately 29,582 in IES1995, 26,263 in IES 2000, 21,144 in IES 2005 and 25,328 in 2010. The sample size was 2668, 3104, 1951 and 3306 for the various years for Limpopo province, respectively.

\section{Empirical methodology}

The aim of poverty measures is to determine the extent of poverty in a country or society. This helps in measuring the welfare of people in a country who are most vulnerable to economic situations, the nature of deprivation among people, people's wellbeing and a society's standards of living (Alkire and Foster 2011; Bossert, Chakravarty, and D'Ambrosio 2013). Generally, poverty can be measured using objective and/or subjective approaches. The objective approach is based on determining the minimum consumption bundle for the food/ non-food items essential for survival, by fixing a measurable value upon which distinctions can be made between poor and non-poor individuals (Bossert, Chakravarty, and D'Ambrosio 2013). This approach is attached to the cardinal pattern (that is, can be counted; for instance, income is cardinal) of poverty assessment. The subjective approach involves selfevaluation by individuals to decide whether they feel poor or not. This approach is grounded on the qualitative analyses of poverty and adopts the ordinal pattern (the opposite of cardinal; ordered water is ordinal) of poverty valuation (Ravallion 1992; Ferrer-I-Carbonell and Van Praag 2001).

The income/consumption approach at individual or household level is most widely used when measuring poverty (Woolard and Leibbrandt 1999; Govender et al. 2007). Data on consumption are preferred because it is believed that these data are more reliable and capture long-run welfare levels much better than income data. That is, in comparison, consumption may better measure and reflect a household's ability to meet its basic needs than income (Ravallion 1992). Furthermore, income varies more over time, while expenditure is often smoothed, and depicts a more reliable and actual consumption level, particularly among poor groups (Coudouel et al 2004; Govender et al. 2007). In this research, the consumption method was used.

According to Woolard and Leibbbbrandt (2001), the majority of questions in the household surveys are asked at household level, while questions regarding, for example, gender and age, are asked at individual levels. Since income and expenditure data are derived from household surveys, they are difficult to split to individual level. The measurement of poverty is therefore done at the household level. Also, household members share electricity and food expenditure, making it difficult to break down household level variables to individual level. Due to differences in household composition and size, it could be misleading to do a simple comparison of total household consumption (Lanjouw \& Ravallion 1994; Woolard and Leibbbbrandt 2001). Moreover, in order to take into consideration, the dissimilarities in household composition and size, total expenditure by a household is divided by the number of the same adults (known as per capita measure), and attuned to take into account economies of scale, denoted as $\theta$ (Deaton and Muellbabauer 1980; Stats SA, 2008).

The two absolute income poverty lines - lines that indicate the threshold on which poor and non-poor individual's will be distinguished, adopted by Woolard and Leibbrandt (2006) and used in most recent poverty studies in South Africa - are used in this research: the 'lower-bound' which amounts to R322 per capita per month, when decomposed gives R211 used for consumption of essential food and R111 for non-food intakes or $\mathrm{R} 322 \times 12=\mathrm{R} 3864$ per capita per annum in 2000 prices; and the 'upper-bound' which, when decomposed gives R211 for food and R382 for non-food items, amounts to R593 per month or $\mathrm{R} 593 \times 12=\mathrm{R} 7116$ per capita per annum in 2000 prices. The per annum poverty lines are used to estimate how many households consume below or above this threshold. 
In order to measure poverty, the Foster-Greer-Thorbecke (FGT) class of decomposable poverty measure. This measure is used because it examines three poverty measures: headcount index $\left(\mathrm{P}_{0}\right)$, poverty gap index $\left(\mathrm{P}_{1}\right)$ and squared poverty gap index $\left(\mathrm{P}_{2}\right)$. If households are classified according to their income measure and we define household $i=1 \ldots q$, as poor and $i=(q+n) \ldots . n$, as non-poor, the FGT poverty measure is expressed as:

$$
\mathrm{P}_{\propto}=\frac{1}{\mathrm{n}} \sum_{\mathrm{i}=1}^{\mathrm{q}}\left(\frac{\mathrm{z}-\mathrm{y}_{\mathrm{i}}}{\mathrm{z}}\right)^{\propto}, \propto \geq 0
$$

where: $z=$ poverty line,

$Y \mathrm{i}=$ measure of income of the ith household

$n=$ sample size

$q=$ number of poor individuals and

$\alpha=$ poverty aversion parameter (Foster, Greer, and Thorbecke 1984, 762).

The interpretation of $\mathrm{P}_{\alpha}$ varies for every given value of $\alpha$. It should be noted that for all poor households ( $i=1 \ldots$. $\mathrm{q}),\left(\mathrm{z}-\mathrm{y}_{\mathrm{i}}\right)$ is positive because they earn less than the poverty cut-off point.

\section{Head-count index $\left(P_{0}\right)$}

It indicates the proportion of people living below a given poverty line in a country or society. It is stated as:

$$
\text { When } \propto=0, \quad \mathrm{P}_{\propto}=\mathrm{P}_{0}=\mathrm{q} / \mathrm{n}
$$

The advantage of $\mathrm{P}_{0}$ is that, it is easy to compute and understand (Coudouel et al, 2004; Mbuli 2008; Woolard et al, 2009). As such, it is often used research to analyze poverty in a region (for example, see Hoogeveen and Özler 2004; Armstrong, Lekezwa, and Siebrits 2008). The weakness of this ratio is that it does not give the depth (gap) and the severity of poverty (Ijaiya and Nuhu 2011). As such, it violates Sen's first two axioms of Sen 1976 (Johnson, 1996). Due to these drawbacks, $\mathrm{P}_{0}$ should be used concurrently with the poverty gap ratio, which is the case in this research.

\section{Poverty gap index $\left(P_{1}\right)$}

It is the difference between the poverty line and the income per capita of a given household (Woolard and Leibbrandt 1999). It is expressed as:

$$
\text { When } \begin{aligned}
\propto & =1, \quad \mathrm{P}_{\propto}=\mathrm{P}_{1} \\
& =\frac{1}{\mathrm{n}} \sum_{\mathrm{i}=1}^{\mathrm{q}}\left(\frac{\mathrm{Z}-\mathrm{Yi}}{\mathrm{Z}}\right)
\end{aligned}
$$

The advantages of this are it reveals the average shortfalls of poor individuals, thus providing a clear picture of poverty depth; also, when multiplied by the given poverty line, $\mathrm{P}_{1}$ indicates the amount that has to be transferred to the poor in an economy to move their expenditure above the poverty line (May, Woolard, and Klasen 2000; Kaplan and Makoka 2005). Hence, from $P_{1}$ it is easy to obtain the least cost of eradicating poverty with transfers. That is, the cost of eradicating poverty by targeting the correct poor group, with no distortion or targeting costs. The main shortfall of the $P_{1}$ index is that it does not take into account the variances in the severity of poverty between poor persons and ignores inequality amid poor individuals themselves.

\section{Squared poverty gap index $\left(P_{2}\right)$}

$\mathrm{P}_{2}$ shows how poverty is distributed below a given poverty line. It is often calculated as severity of poverty measure and can be seen as the sum of an amount, resulting from the poverty gap and inequality amongst poor people (Ravallion 1992).

$\mathrm{P}_{2}$ is expressed as:

$$
\mathrm{P}_{2}=\frac{\left(\mathrm{P}_{1}\right)^{2}}{\mathrm{P}_{0}}+\frac{\left(\mathrm{P}_{0}-\mathrm{P}_{1}\right)^{2}}{\mathrm{P}_{0}} \mathrm{C}_{\mathrm{q}}^{2}
$$

(Contribution of the poverty gap)

where, $C_{q}^{2}=$ squared coefficient of variation of income among poor individuals or group.

The advantages of $\mathrm{P}_{2}$ are: apart from capturing the gap between poor people from the poverty line that is, the poverty gap, it also identifies inequality amongst poor individuals; the value helps us to make comparisons over space or time or between different policy options (Woolard and Leibbbbrandt 2001). $P_{2}$ is needed as $P_{1}$ might not indicate the distributional changes of the population's poor fragment adequately. For instance, if there is a policy in place, that has an effect on cash transfer from someone slightly beneath the poverty line to the poorest individual; $\mathrm{P}_{1}$ would not be able to reflect this change, but $\mathrm{P}_{2}$ would. At all times, $\mathrm{IP}_{2} \mathrm{I}$ when taken into account on its own tells us very little about poverty.

It is not easily interpreted as $\mathrm{P}_{0}$ and $\mathrm{P}_{1}$ even though it weights the poorest of the poor more heavily in its calculation, thus, not widely used (Woolard and Leibbrandt 1999; Kaplan and Makoka 2005; Woolard et al, 2009). The $\mathrm{P}_{\propto}$ index satiates Sen's transfer axiom, which states that, when income is transferred from a poor household to a rich one, measured poverty rises. Another advantage of the $\mathrm{P}_{\propto}$ measure is that, it is decomposable by population subcategories. Hence, the overall poverty measure can be expressed as the sum of group measures, weighted by the population share of respective group (Kaplan and Makoka 2005).

Model for regression analysis: In carrying out empirical analysis on the relationship between education and poverty, most previous studies used the probit regression model for instance, Botha (2010). This model is suitable in this case because the dependent variable which is poverty is binary in nature and takes on two values; poor or non-poor, which will be denoted as 1 and 0 , respectively (Gujarati 2003). A household is considered poor if its head's consumption expenditure falls below R3 864 or R7116 per annum and non-poor if annual income is above R3 864 or R7116 per annum. Also, the model allows the reporting of changes in the response probability that is marginal effects (Gujarati 2003).

During the model specification, emphasis is on whether educational attainment has any significant 
impact on household poverty in South Africa, looking at Limpopo Province in particular. The validity of the model was tested using a-priori expectation, which is based on the signs and magnitude of the coefficient $(\beta)$ of the variables under investigation. $\beta$ measures the marginal effect of the regressors on the regressand. The marginal effect is assessed using the mean values of the regressors used. It indicates how much the dependent variable (poverty) changes when the independent variable changes (Gujarati 2003). In a probit model with many independent variables, the model for the marginal effect is given as:

$$
\begin{aligned}
& \frac{\mathrm{d} \rho}{d x}(\text { Poor }=1 \mid \mathrm{X})=\mathrm{F}\left[\beta_{0}+\sum\left(\beta_{1} \mathrm{LE}+\beta_{2}\right. \text { FEMALE }\right. \\
& \left.\left.\quad+\beta_{3} \text { BLACK }+\beta_{4} \text { RURAL }+\beta_{5} \text { HHSIZE }\right)\right]
\end{aligned}
$$

The specific details of each explanatory variable are provided in Table 1. The characteristics describing the individual households include; educational attainment level [none

Table 1: List of explanatory variables for the probit regression

\begin{tabular}{|c|c|}
\hline $\begin{array}{l}\text { Explanatory } \\
\text { variables }\end{array}$ & Description of variables \\
\hline LE & $\begin{array}{l}\text { Educational level attained by household } \\
\text { head: } \\
\text { None dummy: } 0=\text { No, } 1=\text { Yes: } \\
\text { Primary education dummy: } 0=\mathrm{No}, 1= \\
\text { Yes } \\
\text { Secondary education dummy: } 0=\mathrm{N} 0,1 \\
=\text { Yes } \\
\text { Matric education dummy: } 0=\mathrm{No}, 1=\text { Yes } \\
\text { Post-matric education dummy: } 0=\mathrm{No}, 1 \\
=\text { Yes }\end{array}$ \\
\hline FEMALE & $\begin{array}{l}\text { Gender of household head: } \\
\text { Male dummy: } 0=\text { No, } 1=\text { Yes } \\
\text { Female dummy: } 0=\text { No, } 1=\text { Yes }\end{array}$ \\
\hline BLACK & $\begin{array}{l}\text { Population group of household head: } \\
\text { Black dummy: } 0=\text { No, } 1=\text { Yes } \\
\text { Coloured dummy: } 0=\text { No, } 1=\text { Yes } \\
\text { Indian dummy: } 0=\text { No, } 1=\text { Yes } \\
\text { White dummy: } 0=\text { No, } 1=\text { Yes }\end{array}$ \\
\hline RURAL & $\begin{array}{l}\text { Area type of household head: } \\
\text { Urban dummy: } 0=\text { No, } 1=\text { Yes } \\
\text { Rural dummy: } 0=\text { No, } 1=\text { Yes }\end{array}$ \\
\hline HHSIZE & Size of the household \\
\hline
\end{tabular}
model. (reference group), primary, secondary, matric and postmatric (matric + certificate/diploma and degree combined, due to the small sample size of degree holders)], racial classification [black (reference group), coloured, Indian and white], gender type [male (reference group) and female] of the household head, area type [urban (reference group) and rural] and the household size (HHsize). The age of household heads was not included as a predictor variable because the main focus of the thesis is not on poverty distribution. Also, studies done by Botha (2010) and Ijaiya and Nuhu (2011) on similar work did not include it.

\section{Results and analysis \\ Descriptive statistics}

As indicated in Table 2, using the lower bound poverty line of R3864 over these years, there was an increase in the headcount index from 1995 to 2000 that is, by 0.188 and 0.11 respectively, which then dropped from 2000 to 2010 by 0.163 and 0.166 for Limpopo province and South Africa respectively. The poverty gap and squared poverty gap increased by 0.154 and 0.12 respectively from 1995 to 2000 for Limpopo province and by 0.096 and 0.081 respectively nationally, which then dropped by 0.146 and 0.13 respectively from 2000 to 2005 and slightly increased by 0.002 and 0.017 respectively from 2005 to 2010 for Limpopo province. For South Africa, it decreased by 0.125 and 0.97 respectively from 2000 to 2010 . Using the upper bound poverty line of R7116 over these years, there was an increase in the headcount index by 0.144 and 0.081 , poverty gap by 0.160 and 0.097 and squared poverty gap by 0.15 and 0.093 from 1995 to 2000 for both Limpopo province and South Africa respectively, which then dropped as follows: the headcount, 0.101 and 0.14 ; the poverty gap, 0.134 and 0.138 ; and the squared poverty gap, 0.132 and 0.123 from 2000 to 2010 for both Limpopo province and South Africa respectively.

Considering IES 2010, Limpopo province and these poverty lines, the headcount ratio of 0.596 and 0.777 respectively represent $59.6 \%$ and $77.7 \%$ of households in Limpopo province whose level of consumption is below the aforementioned poverty lines. These figures indicate that $59.6 \%$ and $77.7 \%$ of households in the province are poor since their head's consumption-expenditure level falls below the set poverty lines at the time of this survey. This is higher than the national rate of $40.6 \%$ and $58.3 \%$ respectively. The poverty gap ratio of $29.0 \%$ and $48.1 \%$ respectively, represent those whose average consumption-

\begin{tabular}{|c|c|c|c|c|c|c|c|c|}
\hline \multirow[b]{2}{*}{ Poverty line } & \multicolumn{2}{|c|}{1995} & \multicolumn{2}{|c|}{2000} & \multicolumn{2}{|c|}{2005} & \multicolumn{2}{|c|}{2010} \\
\hline & $\mathrm{L}$ & SA & $\mathrm{L}$ & SA & $\mathrm{L}$ & SA & $\mathrm{L}$ & SA \\
\hline \multicolumn{9}{|l|}{ R3864 } \\
\hline Headcount $\left(\mathrm{P}_{\mathrm{o}}\right)$ & 57.1 & 46.2 & 75.9 & 57.2 & 63.9 & 47.3 & 59.6 & 40.6 \\
\hline Poverty Gap $\left(\mathrm{P}_{1}\right)$ & 28.0 & 22.2 & 43.4 & 31.8 & 28.8 & 21.7 & 29.0 & 19.3 \\
\hline Squared Poverty Gap $\left(\mathrm{P}_{2}\right)$ & 17.0 & 13.3 & 29.0 & 21.4 & 16.0 & 12.6 & 17.7 & 11.7 \\
\hline \multicolumn{9}{|l|}{ R7116 } \\
\hline Headcount $\left(\mathrm{P}_{\mathrm{o}}\right)$ & 73.4 & 64.2 & 87.8 & 72.3 & 81.7 & 65.2 & 77.7 & 58.3 \\
\hline Poverty Gap $\left(\mathrm{P}_{1}\right)$ & 45.5 & 37.7 & 61.5 & 47.4 & 49.8 & 38.2 & 48.1 & 33.6 \\
\hline Squared Poverty Gap $\left(\mathrm{P}_{2}\right)$ & 32.0 & 26.0 & 47.0 & 35.3 & 34.0 & 26.0 & 33.8 & 23.0 \\
\hline
\end{tabular}

Table 2: Trend in headcount, poverty gap and squared poverty gap in percentages for Limpopo province and South Africa.

Source: Researchers own calculations using IES 1995, 2000, 2005 and 2010 data

Note: $L=$ Limpopo and $S A=$ South Africa 
expenditure is below these poverty lines. This gap indicates the degree of poverty of poor households, thus representing the percentage of expenditure required to bring each poor household below these poverty lines up to these poverty lines. Compared to the national rate of $19.3 \%$ and $33.6 \%$ respectively, this is much higher. The squared poverty gap index of 0.177 and 0.338 represent $17.7 \%$ and $33.8 \%$ respectively of the poorest of the poor households in Limpopo province that required special attention by policymakers in the distribution of social amenities, for instance, education, clean water, sanitation and health care facilities, income-generating activities and food that will help improve their living standards. This is higher than the national level of $11.7 \%$ and $23.0 \%$ respectively. The same explanation applies for the previous years.

Comparing IES 1995 and 2010 for Limpopo province, and using these poverty lines, the headcount ratio increased by $2.5 \%$ and $4.3 \%$ respectively in 2010 , indicating additional $2.5 \%$ and $4.3 \%$ of households in the province became poor since their head's consumption-expenditure level fell below the set poverty lines at the time of IES 2010. The poverty gap ratio increased by $1 \%$ and $0.7 \%$ respectively. This shows that an additional $1 \%$ and $0.7 \%$ expenditure was required to bring each poor household below theses poverty lines up to the poverty lines in 2010 . The squared poverty gap ratio increased by 0.026 and 0.018 respectively, at the time of IES 2010 . This signifies an additional $2.6 \%$ and $1.8 \%$ of the poorest of poor households that required special attention by policymakers in the distribution of social amenities at the time of IES 2010.

In Table 3, the FGT measures are disaggregated by the highest educational level of the household head for Limpopo province. The headcount ratio is higher for households in which the head has primary or no education comparative to households where the head has matric or post-matric education. Moreover, the depth and severity of household poverty is much lower if the household head has matric or post-matric education. Looking at IES $2010,73.6 \%$ and $91.8 \%$ of households whose head had no schooling were poor as their head consumption level falls below these poverty lines R3864 and R7116 respectively, at the time of the survey. While only $18.7 \%$ and $26.2 \%$ of households whose head had post-matric were poor respectively, since their head consumption expenditure falls below these poverty lines respectively.

Households headed by someone located in urban areas on average have a higher level of education than those located in rural areas. Table 4 shows the educational attainment level by household heads in the urban and rural areas of Limpopo province. The results show that for the period 1995, 2000, 2005 and 2010, about 5.5\%, 7.7\%, 4\% and $12.1 \%$ respectively of household heads in the urban areas have degrees, while the rural areas recorded $1.8 \%$, $1.3 \%, 1.5 \%$ and $2.1 \%$ respectively. In terms of no schooling by household heads, the highest occurrence was in the rural areas with about $42.6 \%, 38.9 \%, 33.5 \%$ and $25.2 \%$ in 1995, 2000, 2005 and 2010 respectively, while urban areas recorded the lowest results of $18.8 \%, 10.9 \%, 17.9 \%$ and $5.9 \%$ respectively. In addition, over these years, the percentage of those with no education for both urban and rural areas decreased, except from 2000 to 2005 when the urban areas experienced a $7 \%$ increase in those with no education. Overall, the percentage of those with matric and post-matric (matric plus certificate/diploma and degree) is very low for both settlement types. This explains the disturbingly low percentage of quality skills in this province, particularly in the rural areas. In addition, in the rural areas, household heads with no education in Limpopo province is $25.2 \%$ as opposed to $24.2 \%$ nationally while $2.1 \%$ as opposed to $1.6 \%$ nationally had degrees at the time of this survey.

Furthermore, the educational attainment of individual household heads is highest for whites and lowest for blacks. This is shown in Table 5, where over the period

Table 3: Trend in poverty rate by highest educational attainment in percentages in Limpopo province.

\begin{tabular}{|c|c|c|c|c|c|c|c|c|}
\hline & & & & & & & & \\
\hline & R3864 & R7116 & R3864 & R7116 & R3864 & R7116 & R3864 & R7116 \\
\hline Po & 74.4 & 88.7 & 86.5 & 96.2 & 75.1 & 93.0 & 73.6 & 91.8 \\
\hline $\mathrm{P}_{1}$ & 38.1 & 58.4 & 49.8 & 69.1 & 33.6 & 58.4 & 33.5 & 57.3 \\
\hline $\mathrm{P}_{2}$ & 23.7 & 42.7 & 32.8 & 53.3 & 18.4 & 40.0 & 19.0 & 39.6 \\
\hline Pri & & & & & & & & \\
\hline Po & 63.8 & 82.7 & 84.7 & 94.5 & 73.7 & 92.5 & 63.5 & 87.3 \\
\hline$P_{1}$ & 31.5 & 51.3 & 50.7 & 69.1 & 34.2 & 57.0 & 30.6 & 52.4 \\
\hline$P_{2}$ & 19.2 & 36.3 & 34.7 & 54.0 & 19.4 & 39.6 & 18.2 & 36.1 \\
\hline Sec & & & & & & & & \\
\hline Po & 52.2 & 72.4 & 72.4 & 87.7 & 61.4 & 80.4 & 61.9 & 78.7 \\
\hline $\mathrm{P}_{1}$ & 23.4 & 42.1 & 40.0 & 59.1 & 27.8 & 48.1 & 32.1 & 50.3 \\
\hline $\mathrm{P}_{2}$ & 13.0 & 28.4 & 26.5 & 44.2 & 15.9 & 33.0 & 20.7 & 36.5 \\
\hline Ma & & & & & & & & \\
\hline Po & 20.2 & 36.8 & 47.5 & 64.1 & 41.4 & 59.4 & 39.4 & 54.9 \\
\hline $\mathrm{P}_{1}$ & 7.6 & 17.8 & 23.5 & 38.0 & 16.0 & 32.1 & 18.5 & 31.9 \\
\hline $\mathrm{P}_{2}$ & 4.2 & 10.6 & 14.5 & 26.8 & 7.5 & 20.2 & 11.2 & 22.0 \\
\hline Pos & & & & & & & & \\
\hline $\mathrm{P}_{0}$ & 4.4 & 12.8 & 12.8 & 26.8 & 14.9 & 21.7 & 18.7 & 26.2 \\
\hline $\mathrm{P}_{1}$ & 1.0 & 3.7 & 5.3 & 11.9 & 6.7 & 12.3 & 9.0 & 15.2 \\
\hline $\mathrm{P}_{2}$ & 0.3 & 1.7 & 3.1 & 7.1 & 3.6 & 8.1 & 5.4 & 10.5 \\
\hline
\end{tabular}

Source: Researchers own calculations using IES 1995, 2000, 2005 and 2010 data

Note: Figures might not add up due to rounding up or down. 
Table 4: Trend in educational attainment by area type in percentages in Limpopo province.

\begin{tabular}{|c|c|c|c|c|c|c|c|c|}
\hline \multirow[b]{2}{*}{ Educational attainment } & \multicolumn{2}{|c|}{1995} & \multicolumn{2}{|c|}{2000} & \multicolumn{2}{|c|}{2005} & \multicolumn{2}{|c|}{2010} \\
\hline & Urban & Rural & Urban & Rural & Urban & Rural & Urban & Rural \\
\hline None & 18.8 & 42.6 & 10.9 & 38.9 & 17.9 & 33.5 & 5.9 & 25.2 \\
\hline Primary & 14.1 & 16.5 & 16.0 & 25.5 & 7.9 & 24.5 & 13.7 & 26.2 \\
\hline Secondary & 28.3 & 24.9 & 39.1 & 27.5 & 36.5 & 30.2 & 35.1 & 34.5 \\
\hline Matric & 16.0 & 5.4 & 14.8 & 3.7 & 20.4 & 6.6 & 19.5 & 6.9 \\
\hline Matric + certificate/diploma & 9.5 & 5.6 & 10.1 & 2.1 & 13.2 & 3.3 & 12.7 & 3.5 \\
\hline Degree & 5.5 & 1.8 & 7.7 & 1.3 & 4.0 & 1.5 & 12.1 & 2.1 \\
\hline Total & 100 & 100 & 100 & 100 & 100 & 100 & 100 & 100 \\
\hline
\end{tabular}

Source: Researcher's own calculations using IES 1995, 2000, 2005 and 2010 data

Note: Figures might not add up to 100 due to rounding up or down.

1995, 2000, 2005 and 2010, approximately 41.5\%, 35.7\%, $32.6 \%$ and $23.3 \%$ respectively of black household heads had no schooling, while $0.4 \%$ white household heads in 1995 and $0 \%$ in both 2000 and 2005, and $0.4 \%$ in 2010 respectively had no schooling. In addition, the percentages of degree-holders in black household heads were $1.8 \%$, $1.9 \%, 1.7 \%$ and $3.1 \%$; for whites, $14.6 \%, 14.3 \%$ and $6.8 \%$ in 1995,2000 and 2005 , and $14.6 \%$ in 2010 respectively held a degree. Overall, the percentage of household heads with post-matric was highest for whites. Whites also had the lowest percentage for those with only primary or no education. The converse was shown for their black counterparts across these periods. Similar trends were noted nationally.

Finally, female household heads have lower educational attainment than male. As shown in Table 6, at the time of |IES 1995, 2000, 2005 and 2010 approximately $34.8 \%, 23.4 \%, 18.6 \%$ and $15.1 \%$ respectively of male heads had no schooling and while $49.6 \%, 45.3 \%$, $42.5 \%$ and $29.7 \%$ in $1995,2000,2005$ and 2010 respectively of female heads had no schooling. In addition, at the time of these surveys, the percentages of female heads with degrees were $0.6 \%, 0.9 \%, 0.6 \%$ and $1.8 \%$, and $3.1 \%, 3.6 \%, 3.8 \%$ and $5.1 \%$ for male heads in 1995 , 2000,2005 and 2010 respectively. Generally, the percentage of household heads with post-matric is higher for males than females across these periods. One can assume that one of the reasons females were less educated than males was because of pregnancy which might have caused some of them to drop out of school. This could be one of the reasons why poverty is more prevalent amongst female than males as they do not have the required skills gained through education to secure lucrative jobs.

The next section, using a probit regression model, looks at the impact of the explanatory variables, particularly educational attainment on the probability of an individual household being poor in each poverty line.

\section{Regression analysis}

To determine the effect of the explanatory variables on the probability of an individual household being poor in each poverty line, probit regressions were run for the different data sets. For better analysis and due to the small sample size of those with degrees, it was combined with matric + certificate/diploma as post-matric (Wanka 2014). All the perfectly predicted outcomes were omitted from the result as seen in Table 7. This implies that for the given poverty lines and IES 1995 no Indian household head was poor at the time of this survey. The same conclusion applies for coloureds, Indians and whites that were omitted from the IES 2005 results for the lower bound poverty line and whites for the upper bound poverty line.

Holding the other variables constant, based on a-priori grounds, the coefficient estimates of educational attainment for 1995 have the expected sign; likewise for 2000 and 2010, when using the poverty line of R7116 per annum. The a-priori expectation result indicates that the higher the number people with low educational attainment in Limpopo province, the higher the poverty incidence. This is in accord with Todaro (1977), who noted that in developing countries the high poverty level makes it difficult for most people either to attend, complete or even advance with their schooling. This is due to the direct costs involved which include school fees and cost of books and clothing, which is compounded by decreasing income and wages of the individuals, which negatively affects their schooling aspirations. Except for the coefficient of coloureds, the other variables were statistically significant at $1 \%$ level of significance, considering the R3864 per annum poverty line in 1995. From the poverty line of R7116 per annum for the period 19952010 , most of the estimated coefficients were statistically significant at the $1 \%$ significance level, except the coefficient estimate for primary and secondary (from 2000 to 2010), matric (2005), coloureds and Indians, which were insignificant.

The number of units of change and direction in the dependent variable resulting from one unit change in each explanatory variable is shown by the $\beta$ values for education and poverty while holding the other explanatory variables constant. The result shows that a more educated individual is less likely to be poor. Considering IES 1995 and 2010, and a 1\% significance level, at the R3864 poverty line, and controlling for the effects of race, gender, area type and household size, the result indicates that a household with a head who has matric is $32.79 \%$ and $9.29 \%$ respectively less likely to be poor than a household with the head with no education, whereas a similar household is $42.30 \%$ and $16.86 \%$ respectively less likely to be poor when using the R7116 poverty line. In addition, where the head has post-matric education, the likelihood of the household being poor is $45.89 \%$ and $30.88 \%$ respectively at $\mathrm{R} 3864$ poverty line and $64.35 \%$ and $49.35 \%$ respectively at R7116 poverty line. These are 
Table 5: Trend in educational attainment by race in percentages in Limpopo province.

\begin{tabular}{|c|c|c|c|c|c|c|c|c|c|c|c|c|c|c|c|c|}
\hline \multirow{2}{*}{ Educational attainment } & \multicolumn{4}{|c|}{1995} & \multicolumn{4}{|c|}{2000} & \multicolumn{4}{|c|}{2005} & \multicolumn{4}{|c|}{2010} \\
\hline & B & $\mathrm{C}$ & I & W & B & $\mathrm{C}$ & I & W & B & $\mathrm{C}$ & I & W & B & $\mathrm{C}$ & I & W \\
\hline None & 41.5 & 5.1 & 0.0 & 0.4 & 35.7 & 50.6 & 9.5 & 0.0 & 32.6 & 11.7 & 0.0 & 0.0 & 23.3 & 17.9 & 0.0 & 0.4 \\
\hline Primary & 16.6 & 8.7 & 8.9 & 5.9 & 24.6 & 37.4 & 40.2 & 0.0 & 23.4 & 0.0 & 0.0 & 0.0 & 25.2 & 0.0 & 0.0 & 0.0 \\
\hline Secondary & 25.1 & 23.1 & 32.4 & 29.5 & 29.1 & 12.0 & 12.0 & 31.7 & 31.1 & 62.2 & 17.5 & 50.5 & 34.6 & 62.9 & 47.9 & 26.3 \\
\hline Matric & 5.9 & 17.0 & 44.1 & 23.9 & 4.8 & 0.0 & 5.2 & 32.4 & 7.4 & 26.1 & 45.2 & 49.5 & 8.1 & 12.5 & 19.5 & 30.6 \\
\hline Matric + certificate/diploma & 5.5 & 5.1 & 0.0 & 22.4 & 2.9 & 0.0 & 0.0 & 21.7 & 3.7 & 0.0 & 31.3 & 34.9 & 4.3 & 0.0 & 15.1 & 28.2 \\
\hline Degree & 1.8 & 0.0 & 14.7 & 14.6 & 1.9 & 0.0 & 33.1 & 14.3 & 1.7 & 0.0 & 6.1 & 6.8 & 3.1 & 0.0 & 14.1 & 14.6 \\
\hline Total & 100 & 100 & 100 & 100 & 100 & 100 & 100 & 100 & 100 & 100 & 100 & 100 & 100 & 100 & 100 & 100 \\
\hline
\end{tabular}

Source: Researcher's own calculations using IES 1995, 2000, 2005 and 2010 data

Note: $\mathrm{B}=$ Black, $\mathrm{C}=$ Coloured $\mathrm{I}=$ Indian and $\mathrm{W}=$ White

Note: Figures might not add up to 100 due to rounding up or down.

Table 6: Trend in educational attainment in Limpopo province by gender in percentages.

\begin{tabular}{|c|c|c|c|c|c|c|c|c|}
\hline \multirow[b]{2}{*}{ Educational Attainment } & \multicolumn{2}{|c|}{1995} & \multicolumn{2}{|c|}{2000} & \multicolumn{2}{|c|}{2005} & \multicolumn{2}{|c|}{2010} \\
\hline & Male & Female & Male & Female & Male & Female & Male & Female \\
\hline None & 34.8 & 49.6 & 23.4 & 45.3 & 18.6 & 42.5 & 15.1 & 29.7 \\
\hline Primary & 16.7 & 15.6 & 28.5 & 20.5 & 27.1 & 19.2 & 26.9 & 22.7 \\
\hline Secondary & 26.4 & 23.2 & 32.7 & 25.9 & 33.8 & 28.6 & 36.6 & 32.8 \\
\hline Matric & 7.4 & 4.7 & 5.0 & 3.7 & 10.3 & 6.6 & 9.1 & 8.0 \\
\hline Matric + certificate/diploma & 7.9 & 2.6 & 3.8 & 2.6 & 6.9 & 2.5 & 6.0 & 3.5 \\
\hline Degree & 3.1 & 0.6 & 3.6 & 0.9 & 3.8 & 0.6 & 5.1 & 1.8 \\
\hline Total & 100 & 100 & 100 & 100 & 100 & 100 & 100 & 100 \\
\hline
\end{tabular}

Source: Researcher's own calculations using IES 1995, 2000, 2005 and 2010 data

Note: Figures might not add up to 100 due to rounding up or down. 
Table 7: Probit results reporting marginal effects for highest educational level of the household head.

\begin{tabular}{|c|c|c|c|c|c|c|c|c|}
\hline & \multicolumn{2}{|c|}{1995} & \multicolumn{2}{|c|}{2000} & \multicolumn{2}{|c|}{2005} & \multicolumn{2}{|c|}{2010} \\
\hline & 3864 & 7116 & 3864 & 7116 & 3864 & 7116 & 3864 & 7116 \\
\hline \multirow[t]{2}{*}{ Primary } & $-0.0907^{* * *}$ & $-0.0524^{*}$ & 0.0071 & -0.0141 & $0.0712 * *$ & 0.0117 & 0.01870 & $-0.0004^{*}$ \\
\hline & $(0.0276)$ & $(0.0331)$ & $(0.0284)$ & $(0.0237)$ & $(0.0358)$ & $(0.0321)$ & $(0.0279)$ & $(0.0287)$ \\
\hline \multirow[t]{2}{*}{ Secondary } & $-0.1641^{* * *}$ & $-0.1679 * * *$ & $-0.0461^{*}$ & $-0.0352 *$ & 0.0398 & $-0.0579 * *$ & $0.0653^{* *}$ & $-0.0148^{*}$ \\
\hline & $(0.0233)$ & $(0.0271)$ & $(0.0266)$ & $(0.0220)$ & $(0.0316)$ & $(0.0294)$ & $(0.0252)$ & $(0.0257)$ \\
\hline \multirow[t]{2}{*}{ Matric } & $-0.3279 * * *$ & $-0.4230 * * *$ & $-0.2173^{* * *}$ & $-0.2004 * * *$ & $-0.0713^{*}$ & $-0.1222 * * *$ & $-0.0929 * * *$ & $-0.1686^{* * *}$ \\
\hline & $(0.0240)$ & $(0.0345)$ & $(0.0403)$ & $(0.0391)$ & $(0.0488)$ & $(0.0463)$ & $(0.0336)$ & $(0.0365)$ \\
\hline \multirow[t]{2}{*}{ Post-matric } & $-0.4589 * * *$ & $-0.6435^{* * *}$ & $-0.5288^{* * *}$ & $-0.6104 * * *$ & $-0.4024 * * *$ & $-0.6247 * * *$ & $-0.3088^{* * *}$ & $-0.4935^{* * *}$ \\
\hline & $(0.0136)$ & $(0.0189)$ & $(0.0324)$ & $(0.0387)$ & $(0.0358)$ & $(0.0408)$ & $(0.0284)$ & $(0.0325)$ \\
\hline \multirow[t]{2}{*}{ Coloured } & -0.0890 & -0.1413 & 0.0757 & $-0.1106(0.2241)$ & omitted & $-0.2552^{*}$ & -0.1575 & -0.1406 \\
\hline & $(0.1204)$ & $(0.1434)$ & $(0.2517)$ & & & $(0.1663)$ & $(0.1422)$ & $(0.1485)$ \\
\hline \multirow{2}{*}{ Indian } & omitted & Omitted & -0.1906 & -0.1544 & omitted & -0.4195 & 0.0944 & -0.0938 \\
\hline & & & $(0.2352)$ & $(0.1811)$ & & $(0.2921)$ & $(0.1403)$ & $(0.1408)$ \\
\hline \multirow[t]{2}{*}{ White } & $-0.2598 * * *$ & $-0.5025^{* * *}$ & $-0.4219^{* * *}$ & $-0.5636^{* * *}$ & omitted & omitted & $-0.3051^{* * *}$ & $-0.4273^{* * *}$ \\
\hline & $(0.0461)$ & $(0.0484)$ & $(0.0921)$ & $(0.0845)$ & & & $(0.0771)$ & $(0.0890)$ \\
\hline \multirow[t]{2}{*}{ Female } & $0.1737 * * *$ & $0.1258 * * *$ & $0.1963 * * *$ & $0.1419 * * *$ & $0.2027 * * *$ & $0.1570 * * *$ & $0.1396^{* * *}$ & $0.1446^{* * *}$ \\
\hline & $(0.0221)$ & $(0.0219)$ & $(0.0198)$ & $(0.0150)$ & $(0.0251)$ & $(0.0218)$ & (0.0189) & $(0.0184)$ \\
\hline \multirow[t]{2}{*}{ Rural } & $0.2040 * * *$ & $0.2401 * * *$ & $0.2515^{* * *}$ & $0.1984 * * *$ & $0.1555^{* * *}$ & $0.2172 * * *$ & $0.2170^{* * * *}$ & $0.2486^{* * *}$ \\
\hline & $(0.0234)$ & $(0.0263)$ & $(0.0237)$ & $(0.0201)$ & $(0.0345)$ & $(0.0330)$ & $(0.0227)$ & $(0.0239)$ \\
\hline \multirow[t]{2}{*}{ Household size } & $0.0613 * * *$ & $0.0380 * * *$ & $0.0773 * * *$ & $0.0332 * * *$ & $0.0871^{* * *}$ & $0.0650^{* * *}$ & $0.0734 * * *$ & $0.0675^{* * *}$ \\
\hline & $(0.0046)$ & $(0.0047)$ & $(0.0049)$ & $(0.0034)$ & $(0.0064)$ & $(0.0052)$ & $(0.0046)$ & $(0.0048)$ \\
\hline Sample size & 2668 & 2668 & 3104 & 3104 & 1951 & 1951 & 3306 & 3306 \\
\hline Likelihood ratio & $916.38^{(9)}$ & $1031.86^{(9)}$ & $1219.94^{(10)}$ & $1116.86^{(10)}$ & $501.59^{(7)}$ & $545.45^{(9)}$ & $839.76^{(10)}$ & $1083.92^{(10)}$ \\
\hline Prob. $>\mathrm{Chi}^{2}$ & 0.0000 & 0.0000 & 0.0000 & 0.0000 & 0.0000 & 0.0000 & 0.0000 & 0.0000 \\
\hline Log Likelihood & -1374.6077 & -1232.8631 & -1475.1046 & -1093.5345 & -1062.7982 & -844.25069 & -1859.1051 & -1596.5731 \\
\hline
\end{tabular}

Source: Researcher's own calculations using IES $1995,2000,2005$ and 2010 data.
$* * *$ Significant at $1 \% ; * *$ Significant at $5 \% ; *$ Significant at $10 \%$. Note: The powers in brackets on the likelihood ratio values signify the degree of freedom. 
less than a household in which the head has no education.

The same interpretation applies for 2000 and 2005.

With respect to the additional explanatory variables, poverty is higher among female-headed, rural and large households. Moreover, a household with a black head is most likely to be poor compared to their coloured, Indian and white counterparts as shown in Table 7. Keeping all other explanatory variables constant and considering IES 2010 and a $1 \%$ significance level, at the R3864 and R7116 poverty lines, a household headed by a white is $30.51 \%$ and $42.73 \%$ respectively less likely to be poor than that headed by a black. Considering IES 2010 and the poverty lines of R3864 and R7116, and controlling for the effects of gender, area type, education and household size, the result shows that a household headed by a female is $13.96 \%$ and $14.46 \%$ respectively more likely to be poor than that headed by a male. Keeping all other explanatory variables constant, a household whose head resides in rural area is $21.70 \%$ and $24.86 \%$ respectively more likely to be poor than that headed by someone residing in urban areas. Finally, controlling for the effects of the other explanatory variables, the result shows that the larger an increase in the size of a household, the more likely it is for the household to be poor.

\section{Conclusion}

This article has limitations. Firstly, since poverty was measured at household level, specific poverty dynamics within households could not be observed. Secondly, there is the possibility of endogeneity in the regression model. Endogeneity is an issue because though lack of education may lead to poverty, inadequate financial resources might also elucidate the incapability of obtaining a satisfactory educational level. This issue was not controlled due to the absence of a suitable instrumental variable. Hence, the direction of causality between education and poverty is therefore not clear and the estimated parameter(s) cannot be accepted as entirely conclusive. However, the results strongly indicate the evidence that higher education is associated with lower levels of poverty which is in accordance with past research, for instance, Botha (2010), Ijaiya and Nuhu (2011) and Njong (2010).

Comparing the level of poverty in Limpopo province with that of the national level it was found that the poverty rate in Limpopo province was much higher than the national level. But in terms of poverty distribution, poverty is still racially biased with blacks poorer than the other racial groups, and highest in rural areas and amongst females, which, as seen in the literature, is similar to the national level. Over a period of 15 years, using the lower and upper bound poverty lines of R3864 and R7116 per annum respectively, there was an increase of $2.5 \%$ and $4.3 \%$ respectively of households that are poor because their head consumption-expenditure levels fell below the given poverty lines in Limpopo province. The results show that the majority of household heads with no schooling in Limpopo province live in the rural areas and are female and black, while majority with degrees are located in the urban area and are male and nonblack. From the regression result, it is seen that the higher the level of education of an individual, the less likely he or she will be poor. Hence, one can conclude that there is an inverse relationship between education and an individual's poverty status.

The high poverty rate in Limpopo between 2000-2010 can be attributed to the immense shortage of skills which is a manifestation of the generally low educational attainment level in the province. This can be attributed to the sharp decline in government expenditure on education between these years. Hence, based on this study, it is recommended that the government should invest in education, not only in terms of quantity but quality as well. This will greatly improve the skills of its citizens, giving them higher chances to obtain employment in the labour market. This gives recommendation provides room for future research on the relationship between the allocation of resources towards education and the quality of education.

\section{Disclosure statement}

No potential conflict of interest was reported by the authors.

\section{Notes}

1. This article is a revised version extracted from F. A. Wanka's, M.Com (Economics) dissertation on 'the impact of educational attainment on household poverty in South Africa: a case study of Limpopo Province' (2014), under the supervision of Prof R. Rena, submitted to the Department of Economics, University of the Western Cape, South Africa.

2. According to Van der Berg (2008), absolute poverty is the lack of financial resources needed to sustain a given minimum standard of living, while relative poverty is poverty that is mostly determined by the community in which an individual lives. Absolute poverty is rare in developed countries, but predominant in underdeveloped countries (Raffo et al. 2009).

3. Govender et al. (2007) stated that chronic poverty is poverty whereby at each successive observation people are seen to be poor, while temporary poverty means moving from being poor to non-poor.

\section{ORCID}

Ravinder Rena (D) http://orcid.org/0000-0002-4156-8693

\section{References}

Aliber, M. 2001. Study of the Incidence and Nature of Chronic Poverty and Development Policy in South Africa: An Overview. Cape Town: Programme for Land and Agrarian Studies. School of Government: University of the Western Cape.

Alkire, S., and J. Foster. 2011. "Counting and Multidimensional Poverty Measurement." Journal of Public Economics 95 (7): 476-487.

Appleton, S. 2001. Education, Incomes and Poverty in Uganda in the 1990s. Center for Research in Economic Development and International Trade. University of Nottingham. Mimeo.

Armstrong, P., B. Lekezwa, and F. K. Siebrits. 2008. Poverty in South Africa: A Profile Based on a Recent Household Survey. (Stellenbosch Economic Working Papers 04/08). Stellenbosch: University of Stellenbosch.

Badat, S., and Y. Sayed. 2014. "Post-1994 South African Education: The Challenge of Social Justice." The ANNALS 
of the American Academy of Political and Social Science 652 (1): 127-148.

Batana, Y. M. 2013. "Multidimensional Measurement of Poverty among Women in Sub-Saharan Africa." Social Indicators Research 112 (2): 337-362.

Bhorat, H., L. Poswell, and P. Naidoo. 2004. Africa, Dimension of Poverty in Post-Apartheid South Africa 1996-2001. Cape Town: Development Policy Research Unit, University of Cape Town.

Bhorat, H., and C. Van der Westhuizen. 2013. "Non-monetary Dimensions of Well-Being in South Africa, 1993-2004: A Post-Apartheid Dividend?" Development Southern Africa 30: 295-314.

Bloom, D., D. Canning, and K. Chan. 2005. Higher Education and Economic Development in Africa. Washington Dc: World Bank.

Borjas, G. 2016. Labour Economics. 7th Edition. New York: McGraw-Hill Companies, Inc.

Bossert, W., S. R. Chakravarty, and C. D'Ambrosio. 2013. "Multidimensional Poverty and Material Deprivation with Discrete Data." Review of Income and Wealth 59 (1): 29-43.

Botha, F. 2010. "The Impact of Educational Attainment on Household Poverty in South Africa." Acta Academia 42 (4): 122-147.

Coudouel, A., J. S. Hentschel, and Q. T. Wodon. 2004. Poverty measurement and analysis. Core Techniques and CrossCutting Issues, Vol. 1, 27-74. Washington DC: World Bank.

Deaton, A., and J. Muellbabauer. 1980. "An Almost Ideal Demand System." The American Economic Review 70 (3): 312-26.

Ferrer-I-Carbonell, A., and B. M. S. Van Praag. 2001. "Poverty in Russia." Journal of Happiness Studies 2: 147-172.

Foster, J., J. Greer, and J. Thorbecke. 1984. "A Class of Decomposable Poverty Measures." Econometrica 52 (3): 761-6.

Govender, P., N. Kambabaran, N. Patchchett, A. Ruddle, G. Torr, and N. Van Zyl. (2007). "Poverty and Inequality in South Africa and the World." South African Actuarial Journal 7: 117-60.

Gujarati, D. 2003. Basic Econometrics. 4th edition. New York: McGraw Hill. University of Stellenbosch.

Hoogeveen, J. G., and B. Özler. 2004. Not Separate, Not Equal: Poverty and Inequality in Post-Apartheid South Africa. Washington, DC: World Bank.

Hoogeveen, J. G., and B. Özler. 2006. "Poverty and Inequality in Post-Apartheid South Africa:1995-2000." In Poverty and Policy in Post-Apartheid South Africa, edited by $\mathrm{H}$. Bhorat, and R. Kanbur, 59-94. Cape Town: Human Sciences Research Council.

Ijaiya, G., and M. Nuhu. 2011. "Low Educational Attainment and the Incidence of Poverty in Ilorin Metropolis." Nigeria. International Review of Social Sciences and Humanities 2 (1): 81-90.

Jansen, A., M. Moses, S. Mujuta, and D. Yu. 2015. "Measurements and Determinants of Multifaceted Poverty in South Africa." Development Southern Africa 32 (2): $151-169$.

Johnson, D. 1996. "Poverty Lines and the Measurement of Poverty." Australian Economic Review 29 (1): 110-126.

Kaplan, M., and D. Makoka. 2005. Poverty and vulnerability - an interdisciplinary Approach. Term Paper, Unpublished. Available [Online]: http://mpra.ub.uni-muenchen.de/6964/.

Kjelland, J. 2008. "Economic Returns to Higher Education: Signaling VS Human Capital Theory; an Analysis of Competing Theories." The Park Place Economist 16 (1): 70-77.

Klasen, S. 1997. "Poverty, Inequality and Deprivation in South Africa: an Analysis of the 1993 SALDRU Survey." Social Indicators Research 4 (1): 51-94.

Leibbrandt, M., D. Lam, N. Branson, and J. Garlick. 2012. Education and Inequality: The South African Case. In: Southern Africa Labour and Development Research Unit Working Papers. 75.
Leibbrandt, M., I. Woolard, A. Finn, and J. Argent. 2010. Trends in South African Income Distribution and Poverty Since the Fall of Apartheid. OECD Social, Employment and Migration Working Papers, 101. Paris: OECD Publishing.

Levels, M., R. Van der Velden, and V. Di Stasio. 2014. "From School to Fitting Work: How Education-to-job Matching of European School Leavers is Related to Educational System Characteristics." Acta Sociologica 57 (4): 341-361.

Macerinskiene, I., and B. Vaiksnoraite. 2006. The role of higher education to economic development. Vadyba / Management 2 (11): 82-90

Mamman, A., K. Kamoche, H. B. Zakaria, and M. Agbebi. 2018. "Developing Human Capital in Africa: Carving a Role for Human Resource Professionals and Practitioners." Human Resource Development International, 1-19.

May, J., I. Woolard, and S. Klasen. 2000. "The Nature and Measurement of Poverty." In Poverty and Inequality in South Africa: Meeting the Challenge, edited by J. May. Cape Town.

Mbuli, B. N. 2008. Poverty Reduction Strategies in South. University of South Africa (Dissertation - Master's Degree).

McKay, V. 2007. "Adult Basic Education and Training in South Africa." Review of Adult Learning and Literacy 7 (9): 285 310.

Mokgotho, R. F. 2010. "Problems Affecting the Sustainability of Income-generating Project at Hlatlolang ABET Centre." Master's Degree Dissertation, University of Limpopo.

Naeem, T. 2013. "Whither the Public University: Funding Constraints." International Journal Technology, Policy and Management 13 (4): 396-408.

Navaratnam, K. K. 1986. Role of education in rural development. A key factor for developing countries. Virginia, USA: Centre for Volunteer Development.

Njong, A. M. 2010. The effects of educational attainment on poverty reduction in Cameroon. Journal of Education Administration and Policy Studies 2 (1): 1-8.

Page, M. E. 2010. "Signalling in the Labour Market." In International Encyclopedia of Education (3rd Ed.), edited by Penelope Peterson, Eva Baker and Barry McGaw, 321-324. Elsevier. https://doi.org/10.1016/B978-0-08-044894-7.01214-8.

Palmer, R., R. Wedgwood, R. Hayman, K. King, and K. Thin. 2007. "Educating out of Poverty? A Synthesis Report on Ghana, India, Kenya, Rwanda, Tanzania and South Africa." Researching the Issues 70: 5-102.

Pauw, K., H. Bhorat, S. Goga, L. Ncube, and C. Van Der Westhuizen. 2006. Graduate unemployment in the context of skills shortages, education and training: Findings from a firm survey. Development Policy Research Unit, Working Paper 06/115 University of Cape Town.

Raffo, C., A. Dyson, H. Gunter, D. Hall, L. Jones, and A. Kalambouka. 2009. "Education and Poverty: Mapping the Terrain and Making the Links to Educational Policy." International Journal of Inclusive Education 13 (4): 341-358.

Ravallion, M. 1992. Poverty Comparisons: A Guide to Concepts and Methods. (Living Standards Measurement Study Working Paper 88.). Washington, DC: World Bank.

Schuster, J. 2011. "The Same Education for all? The South African School System 17 Years After the end of Apartheid." Kas International Reports 7: 40-56.

Spaull, N. 2015. "Schooling in South Africa: How low-Quality Education Becomes a Poverty Trap." South African Child Gauge 12: 34-41.

Statistics South Africa. 2008. Measuring poverty in South Africa. Methodololical report in South Africa.

Statistics South Africa. 2017. Financial Statistics of Consolidated General Government. http://www.statssa.gov.za/ publications/P91194/P911942016.pdf accessed 30/08/2018.

Thomson, A. 2008. Exploring the Relationship Between Higher Education and Development: A Review and Report. Guerrand Hermes Foundation for Peace. Available [Online]: http://www.ghfp.org/Portals/0/documents/Thomson HEI_Role_Dev.pdf Retrieved on 15 September 2014. 
Tilak, J. B. G. 2002. "Education and Poverty." Journal of Human Development 3 (2): 191-207.

Todaro, M. P. 1977. Economics for a Developing World: An Introduction to Principles, Problems and Policies for Development. London: Longman Press.

Van der Berg, S. 2002. Education, Poverty and Inequality in South Africa. Unpublished presentation at the Centre for the Study of African Economies on Economic growth and poverty in Africa, Oxford.

Van der Berg, S. 2007. "Apartheid's Enduring Legacy: Inequalities in Education." Journal of African Economies 16 (5): 849-880.

Van der Berg, S. 2008. "How Effective are Poor Schools?" Poverty and Educational Outcomes in South Africa. Studies in Educational Evaluation 34 (3): 145-154.

Von Kotze, A. 2007. Negotiating processes of educating, learning and livelihoods. Paper presented at the December 2007 RWL5 Conference, Cape Town.

Waghid, Y., and D. Schreuder. 2000. "Can Post-structuralist nuances of Sustainable Living Contribute Towards Educational Transformation in Education." South African Journal of Education 20 (2): 85-90.

Wanka, Fru Awah. 2014. "The Impact of Educational Attainment on Household Poverty in South Africa: A Case Study of
Limpopo Province", M.Com (Economics) Dissertation, University of the Western Cape. http://etd.uwc.ac.za/xmlui/ handle/11394/4286.

Weber, B., A. Marre, M. Fisher, R. Gibbs, and J. Cromartie. 2007. "Education's Effect on Poverty: the Role of Migration." Review of Agricultural Economics 29 (3): 437-45.

Weiss, A. 1995. Human Capital vs Signalling Explanation of Wages. The Journal of Economic Perspectives 9 (4): 133-154.

Woolard, I. 2002. An Overview of Poverty and Inequality in South Africa. Working Paper prepared for DFID (SA).

Woolard, I., and M. Leibbrandt. 1999. "Measuring Poverty in South Africa." In Fighting Poverty: Labour Markets and Inequality in South Africa, edited by H. Bhorat, M. Leibbrandt, M. Maziya, S. Van der Berg, and I. Woolard, 41-73. Lansdowne: UCT Press.

Woolard, I., and M. Leibbrandt. 2006. Towards a Poverty Line for South Africa: Background Note. Cape Town: Southern Africa Labour and Development Research Unit. University of Cape Town.

Woolard, I., H. McEwen, and C. Kannemeyer. 2009. Social assistance grants: Analysis of the NIDS Wave 1 Dataset. Unpublished.

World Bank. 2018. Government Expenditure on Education. https://data.worldbank.org/indicator/SE.XPD.TOTL.GD.ZS accessed 6/09/2018. 